\title{
PERSPECTIVES ON PRESCHOOL CURRICULUM IN PORTUGAL
}

\author{
N. Carrachás ${ }^{1}$, F. Seabra ${ }^{2}$, M. Abelha ${ }^{3}$ \\ ${ }^{1} D E E D$, Universidade Aberta (PORTUGAL) \\ ${ }^{2} D E E D$, LE@D, Universidade Aberta (UAb) / CIEd-UMinho; CIPEM/INET-MD (PORTUGAL) \\ ${ }^{3}$ CEIS20, Universidade de Coimbra, Universidade Portucalense, Universidade Aberta (UAb) \\ (PORTUGAL)
}

\begin{abstract}
The present communication is focused on the curriculum of preschools in Portugal (ages 3 to 6 ) and how preschool educators and 1st cycle (ages 6 to 10) teachers, as well as preschool children's parents perceive it.

Firstly, preschool education is contextualized in order to better frame the need for an active investment in the valuing of this educational level. Given its short existence, accompanied by advancements and setbacks, the idea often perceived in social discourse about preschool education in Portugal is often not one of an activity aimed at the global development of children, as assistentialist conceptions persist.

However, while there isn't a structured curriculum for preschool, there are Curricular Guidelines for Preschool Education (CGPE), a set of general principles which contribute to the childhood educators' decisions about their educational practice and the educational intentionality of the activities developed with children. This document is a referential for the national network of preschool education for the construction of curriculum, which retains a wide margin of decision for the contextualization and differentiation of curriculum, acknowledging the childhood educators' role as a curriculum decision maker.
\end{abstract}

The aim of this study was to understand the conception that preschool teachers, $1^{\text {st }}$ cycle teachers and some parents have about this level of education as well as to understand if they recognize the importance of developing personal and social skills together with other content areas which might be a facilitating scafold for the entrance in the following cycle.

This study, using a mixed methodology, included semi-structured interviews to preschool educators (eight interviewees), and questionnaires to $1^{\text {st }}$ cyle teachers (fourty nine) and parents (seventy-eight) of four schools in a region of inner Portugal, the district of Beja.

The research followed the ethical norms for research in the social sciences, namely informed consent by participants and preservation of anonymity. Data gathering instruments were approved by the Ministry of Education as well as by the pedagogical councils and directors of the four school clusters involved.

The main results show that all the preschool educators surveyed base their curriculum building process on the CGPE, some referring to this document as their "Bible» and also as the foundation of their planning and assessment practices. However important the document is deemed, it is not the sole foundation for their curricular decision-making, as children themselves and schools' other internal documents and projects are also taken into account.

Although primary school teachers know about the existence of the CGPE, they don't demonstrate a broad understanding about its content, although they identify practices of coordination with preschool educators to prepare the students' transition between educational cycles. They also recognize that the work carried out in preschool aims to facilitate future learning processes by the children. On the other hand, parents revealed a more passive attitude towards their children's activities in preschool.

Keywords: Preschool, $1^{\text {st }}$ cycle of Basic Education, Curriculum.

\section{INTRODUCTION}

Preschool education (PSE) in Portugal is presented as the first stage of basic education in the process of lifelong learning, encompassing children between the age of 3 to 5 years old. PSE intends to be complementary to the families' educational action, establishing synergies with the families in order to 
promote the balanced development and education of the child, and their fullest insertion in society as an autonomous, free and solidary human being [1].

PSE is distinguished from other stages in education, among other reasons, for not being of mandatory attendance, although it is universal for children above the age of five, and for not having a set curriculum, but rather being guided by a document - Curricular Guidelines for Preschool Education (CGPE) - first published in 1997. This is a referential for the work carried out in the national network of PSE that enables Preschool Educators a wide margin of curricular decision, which is intended to allow contextualization and differentiation. Previous to the CGPE, there was no official document that provided Preschool Educators across the country with a common curricular referential. We stress that the CGPE are not a program to be carried out, but rather a reference to constitute and manage curriculum, which should be adapted to the social context, to the characteristics of the children and families and to the evolution of the learnings of each child and group of children [2].

The conception of curriculum underlying PSE is, according to the CGPE, the set of interactions, experiences, activities, routines and happenings, planned and unplanned, that occur within an inclusive educational environment, organized for the promotion of the well being, development and learning of children [2]. As stated by Sousa [3] this conception, adapted from the New-Zealand curriculum for preschool - Te Whāriki -, is no doubt closer to an experiential perspective than to a prescriptive perspective on curriculum.

Given the importance of the family context in preschool education of children, all the planning of educational practice foresees strategies to include their participation, continuously assessing, adjusting and reformulating approaches as needed. The sharing and joint reflection with other Preschool Educators from the same educational establishment about the development of the work carried out is a privileged means for professional development and improvement of practices. This communication among Preschool Educators may be carried forward, towards communication and articulation with teacher of other levels of education, particularly the $1^{\text {st }}$ cycle of basic education $\left(1^{\text {st }} \mathrm{CBE}\right)$, enabling and facilitating the transmission of information on the learning and development of each child in PSE in order to promote and ease their transition to the $1^{1 \mathrm{st}} \mathrm{CBE}$. This level of education has a curriculum, which is guided by curricular goals, allowing a smaller margin of curricular flexibility, when compared to the CGPE.

However, $1^{\text {st }}$ CBE teachers, parents and other caregivers and preschool educators don't always acknowledge PSE as having a pedagogical intentionality. Is social importance and relevance to the global development of children - including its role in preparing children for subsequent stages of education, namely for the transition to the $1^{\text {st }}$ CBE which comprises the first four years of mandatory education (children ages 6 to 10). Assistentialist perspectives on the nature of PSE, still persist.

In this context, it is pertinent to present data from an empirical study, that lead us to a better understanding of how preschool educators manage curriculum in their classrooms, having the CGPE as guidelines. It is also a challenge to understand the perceptions of parents about preschool curriculum and in what ways they are participating in curriculum development. Lastly, we intended to analyze the positions of $1^{\text {st }}$ CBE teachers towards PSE and what knowledge they have of this level of education, as well as what kinds of articulation practices exist between those two levels of education and teaching.

\section{METHODOLOGY}

The empirical framing for the present research is focused on PSE as an object, and stems from the following problem: How do $1^{\text {st }}$ CBE teachers, parents/ caregivers and preschool educators value, conceive or construct the curriculum of PSE? In order to answer this research question, the following objectives were formulated: i) to characterize the perceptions of $1^{\text {st }} \mathrm{CBE}$ teachers, parents/ caregivers and preschool educators of certain school clusters in the district of Beja about the CGPE; ii) to know the perspectives of preschool educators from school clusters of the district of Beja about the ways in which the CGPE are interpreted in their practice; iii) to know perspectives of $1^{\text {st }}$ CBE teachers from school clusters from the district of Beja about the work carried out by PSE in their school clusters; and iv) to know perspectives of parents / caregivers about the work carried out in PSE. In order to prosecute those objectives a mixed-method research of interpretative and descriptive nature was carried out, assuming an exploratory character.

Data gathering was done using the techniques of inquiry by interview (to preschool educators), inquiry by questionnaire (one questionnaire was directed to $1^{\text {st }} \mathrm{CBE}$ teachers and a different questionnaire to 
parents / caregivers) and documental analysis (directed towards the legal documents that guide PSE and the $1^{\text {st }} \mathrm{CBE}$ as well as the CGPE themselves). The qualitaitive data gathered were subjected to content analysis and the quantitative data were subjected to statistical analysis.

The empirical study took place in four school clusters from the interior south region of Portugal, namely Serpa, Barrancos, Moura and Amareleja, situated in the district of Beja.

The inquiry by interview was directed to eight preschool educators (whose characterization is presented in table 1), two from each of the school clusters encompassed by the study, and with the caution of selecting educators with diverse profiles of professional experience. The initial intention was to interview an educator in the initial stage of the career and one with a longer career, from each school cluster. However, it was not always possible to apply this selection criterion, as in two of the school clusters under consideration all the educators had approximately the same number of years of experience. Interviewees' identities were protected by using identification codes.

Table 1. Characterization of the preschool educators interviewed

\begin{tabular}{c|c|c|c|c|c|c}
\hline \hline Interviewees & School cluster & Gender & Age & $\begin{array}{c}\text { Years of } \\
\text { service }\end{array}$ & $\begin{array}{c}\text { Professional } \\
\text { situation* }\end{array}$ & $\begin{array}{c}\text { Academic } \\
\text { degree** }\end{array}$ \\
\hline E1 & Serpa & $\mathrm{F}$ & 54 & 30 & QA $^{*}$ & $\mathrm{M}$ \\
\hline E2 & Serpa & $\mathrm{F}$ & 58 & 36 & $\mathrm{QA}$ & $\mathrm{G}$ \\
\hline E3 & Barrancos & $\mathrm{F}$ & 57 & 31 & $\mathrm{QA}$ & $\mathrm{G}$ \\
\hline E4 & Barrancos & $\mathrm{F}$ & 49 & 21 & $\mathrm{C}$ ** & $\mathrm{G}$ \\
\hline E5 & Moura & $\mathrm{F}$ & 35 & 12 & $\mathrm{C}$ & $\mathrm{G}$ \\
\hline E6 & Amareleja & $\mathrm{F}$ & 53 & 31 & $\mathrm{QA}$ & $\mathrm{G}$ \\
\hline E7 & Amareleja & $\mathrm{F}$ & 52 & 28 & $\mathrm{QA}$ & $\mathrm{G}$ \\
\hline \hline
\end{tabular}

* Labels: QA - School Cluster Frame (a more stable form of employment); C - Contracted.

** Labels: M - Master; G - Graduate degree (4 years of higher education).

The survey by questionnaire was applied to all $(N=64)$ the 1st $\mathrm{CBE}$ teachers of the four school clusters. Forty nine (49) valid questionnaires were collected, which amounts to an answer percentage of $76,56 \%$. Through the analysis of Table 2, we can verify that the sample of teachers is predominantly female $(80 \%)$, approximately half $(51 \%)$ of the respondents is more than 51 years old, and $80 \%$ has a graduate degree (4 years of higher education).

Table 2. Characterization of the 1st CBE teachers

\begin{tabular}{|c|c|c|c|}
\hline & & Frequency & Percentage \\
\hline \multirow{2}{*}{ Gender } & Female & 39 & $80 \%$ \\
\hline & Male & 10 & $20 \%$ \\
\hline \multirow{7}{*}{ Age } & $20-25$ years & 0 & $0,0 \%$ \\
\hline & 26 - 30 years & 0 & $0,0 \%$ \\
\hline & $31-35$ years & 0 & $0,0 \%$ \\
\hline & $36-40$ years & 7 & $14 \%$ \\
\hline & $41-45$ years & 8 & $16 \%$ \\
\hline & $46-51$ years & 9 & $19 \%$ \\
\hline & $>51$ years & 25 & $51 \%$ \\
\hline \multirow{5}{*}{$\begin{array}{l}\text { Academic } \\
\text { degrees }\end{array}$} & Short higher education degree (3 years) & 2 & $4 \%$ \\
\hline & Graduate Degree (4 years higher education) & 39 & $80 \%$ \\
\hline & $\begin{array}{l}\text { Specialized Program of Higher Education } \\
(3+1 \text { years higher education) }\end{array}$ & 1 & $2 \%$ \\
\hline & Master & 7 & $14 \%$ \\
\hline & Doctorate & 0 & $0 \%$ \\
\hline
\end{tabular}


The inquiry by questionnaire applied to parents / caregivers was applied to a stratified sample of the children's caregivers - one group per school. The selection criterion was that the selected group would be the one with more children and one whose preschool teacher had not been interviewed.

Therefore, 90 questionnaires were distributed to parents /caregivers, corresponding to the number of children in those groups. Sixty-two (62) were answered, corresponding to an answer percentage of $69 \%$.

As expressed by the data in Table 4, we can verify that mothers are the caregivers more frequently in contact with the preschool educators. The predominant age clusters of the parents/ caregivers are those comprehended between ages $31-35$ (31\%), $36-40$ (23\%) and $26-30(19 \%) ; 59 \%$ of parents / caregivers have a secondary education degree (12 years of schooling).

Table 3. Characterization of parents / caregivers

\begin{tabular}{|c|c|c|c|}
\hline & & Frequency & Percentage \\
\hline \multirow{2}{*}{ Gender } & Female & 58 & $94 \%$ \\
\hline & Male & 4 & $6 \%$ \\
\hline \multirow{7}{*}{ Age } & $20-25$ years & 2 & $3 \%$ \\
\hline & $26-30$ years & 12 & $19 \%$ \\
\hline & 31 - 35 years & 19 & $31 \%$ \\
\hline & $36-40$ years & 14 & $23 \%$ \\
\hline & $41-45$ years & 7 & $11 \%$ \\
\hline & $46-51$ years & 7 & $11 \%$ \\
\hline & $>51$ years & 1 & $2 \%$ \\
\hline \multirow{8}{*}{$\begin{array}{l}\text { Academic } \\
\text { degree }^{*}\end{array}$} & $1^{\text {st }} \mathrm{CBE}$ & 1 & $2 \%$ \\
\hline & $2^{\text {nd }} C B E$ & 6 & $10 \%$ \\
\hline & $3^{\text {rd }} \mathrm{CBE}$ & 9 & $14 \%$ \\
\hline & Secondary & 37 & $59 \%$ \\
\hline & 3 years higher education & 1 & $2 \%$ \\
\hline & Graduate Degree & 6 & $10 \%$ \\
\hline & Master & 2 & $3 \%$ \\
\hline & Doctorate & 0 & $0 \%$ \\
\hline
\end{tabular}

*Label: $1^{\text {st }}$ CBE -4 years of schooling; $2^{\text {nd }}$ CBE -6 years of schooling; $3^{\text {rd }}$ CBE -9 years of schooling; Secondary -12 years of schooling; Graduate degree -3 to 6 years of higher education.

\section{RESULTS}

The results presented are of qualitative and quantitative nature. Quantitative data result from the gathering of 49 correctly filled questionnaires to teachers of the $1^{\text {st }} \mathrm{CBE}$ and 62 valid questionnaires to parents/ caregivers of 4 school clusters from the district of Beja. The qualitative data report to the content analysis of 8 interviews to preschool educators from the same school clusters. In this section, we return to the objectives that guided the present research, intending to triangulate the data from different sources and data gathering techniques.

\subsection{To characterize the perceptions of preschool educators, $1^{\text {st }} \mathrm{CBE}$ teachers and parents/ caregivers form school clusters of the district of Beja about the CGPE}

Concerning the CGPE all the preschool educators referred in the interview to have an in-depth knowledge of this document, making frequent use of these guidelines for their educational action namely concerning the planning, evaluation and elaboration of the Group Curricular Project, as is demonstrated in the transcription from the speech of the interviewee codified as E6:

To manage curriculum, in the process of planning, action and evaluation. The areas are a useful contribution because through them we can develop the work in the classroom. 
They are a good referential for the development of learnings. A good orientation of the work of the preschool educator (E6).

Concerning the degree of importance attributed to the CGPE, seven of the interviewees asserted they were very important, as their work is mostly developed having the CGPE as guidelines, as can be noted in the following transcription:

I consider them very important, precisely because they are guidelines. It is a $n$ instrument for our work, which gives us some indications, but simultaneously allows freedom and flexibility for our practices and curriculum (E4).

When questioned about the possibility of making improvement to the CGPE document, interviewee E3 referred to the need for increased articulation with the objectives of the 1st CBE, strategies that promote the transition between PSE and the 1st CBE. Because there is still a lack of knowledge about the contents developed in this level of education.

Most parents / caregivers (89\%) mentioned being aware of the existence of CGPE, however, they referred not to know the content of that document. Despite the fact that most parents / caregivers also revealed not to know much about the CGPE or the work developed based on this document, they acknowledged that their children had advantages in frequenting PSE.

Questioned about the CGPE, the majority $(80 \%)$ of $1^{\text {st }}$ CBE teachers mentioned knowing about the existence of a basis for the curricular work of preschool educators, however, $49 \%$ of respondents admitted not knowing what that basis was. For $86 \%$ of $1^{\text {st }}$ CBE teachers the frequency of PSE by children has great advantages, including the fact that when admitted to the $1^{\text {st }}$ CBE such children reveal: i) more competencies or pre-requisites, which facilitate learning to read and write, as well as in the domain of mathematics; ii) these are children who develop better relations with their peers and with the group, being more sociable; iii) they have a better understanding of the classroom rules, and iv) they present greater autonomy.

To summarize, the CGPE contemplate areas, which are worked and explored in a ludic fashion throughout the three years of PSE and are acknowledged by parents/caregivers and teachers of the $1^{\text {st }} \mathrm{CBE}$ as important to the global development of the children and promoting learnings that will influence the later performance of children in several domains. These conclusions are also supported by Clarke [4], in a study aimed at verifying changes in performance in measures applied over the course of a year in terms of mathematical knowledge, with impacts on the future performance of children in the field of mathematics. This study highlights the importance of early intervention and the possibility of exploring curricular contents as early as PSE.

\subsection{To know the perspective of preschool educators on how the CGPE are interpreted in their practice}

The preschool educators from the school clusters that participated in the study revealed in-depth knowledge of the CGPE and making use of them in order to plan their educational work. However, they pointed out resourcing to other documents as reference (such as the Annual Plan of Activities (APA), the Educational Project of the School Cluster (EPSC) - internal documents of the schools) and other sources among which the children themselves - their interests and needs - are paramount, as can be noted in the speech below:

I carry out projects with the children which are based on their interests, what they know, what they wish to learn, and how they can develop the work (E2).

Regarding this matter, Pestana and Pacheco [5] reinforce that children's learnings are only significant if they interiorize them, participate critically in their construction and are authentic. It is therefore important to allow children an active role in constructing knowledge [5]. Similarly, some preschool educators refer to, using the CGPE as a starting point, involving children in the planning of activities, in their execution and later evaluation of what has been planned and produced.

The work carried out by the preschool educators is not homogenous in terms of the adopted methodologies. However, preschool educators have referred to directing their work by articulating the three major areas of the CGPE - personal and social education; expression and communication; and knowledge of the world. 
The preschool educators recognize the flexibility of the CGPE, arguing these are guidelines, not fixed directives, unlike what is the case in later stages of education, which enables them to assume an active role in the elaboration of curriculum and its adequacy to the group of children with whom they are working. However, they also recognize opportunities for improvement, particularly in what concerns curricular articulation with the $1^{\text {st }} \mathrm{CBE}$. These results reinforce those found by Abreu Lima and collaborators [6], stressing the CGPE lay the foundation for the curricular work of preschool educators. Both results point out the active construction of curriculum by preschool educators based on the OCEPE and the participation of children in that process.

It is also noteworthy that the answers of the preschool educators who participated in the study refer to curricular decisions made at the political/administrative level [7], the CGPE, to the management at the meso level through the structuring documents of their respective school clusters (APA and APSC) and to the dynamics constructed by educators and children who jointly construct the Group Project, resourcing to the methodologies adopted by each preschool educator (micro level). Thus, they assume the transversal nature of curricular decision processes, from the furthest to the nearest - the realization context - which is made real through the action of the preschool educator.

\subsection{To know the perspectives of $1^{\text {st }} \mathrm{CBE}$ teachers about the work carried out at the level of PSE in their school clusters}

According to the perspective of $86 \%$ of the teachers of the $1^{\text {st }}$ CBE, PSE is of great importance as it favors the global development of children. These teachers recognize advantages to PSE in terms of the acquisition of knowledge which facilitate further learning. Seventy-two (72) percent of teachers who answered the questionnaire fully agree that frequenting PSE can positively influence children's future academic performance, making them more able to develop future learning. This vision on the importance and influence of PSE for the global development of children and their future learning is in agreement with the perspectives of the preschool educators who participated in this study.

Teachers from the $1^{\text {st }}$ CBE, similarly to preschool educators, consider PSE works on the different areas contemplated by the CGPE in a transversal and integral fashion, towards the construction of knowledge. Additionally, $70 \%$ of the respondents recognize there are differences among the children who have frequented PSE and those who did not. Among these, $56 \%$ of teachers point out as advantages to children stemming from PSE: i) greater levels of sociability; ii) greater levels of autonomy, and iii) more competencies for learning.

Pertaining the work established between preschool educators and $1^{\text {st }}$ CBE teachers, in general, the respondents state it takes place at the moment of transition from a PSE group to the $1^{\text {st }}$ CBE. Both $1^{\text {st }}$ $\mathrm{CBE}$ teachers and preschool educators refer to participating in articulation activities as is foreseen by the CGPE which emphasize educational continuity and transition, building upon learnings which have already been established. First CBE teachers attribute importance to the learnings children have made in PSE, leading them to acknowledge the work developed at that level of education. Despite not knowing in depth how exactly how such learnings take place, they seem to recognize the value of positive outcomes to the children frequenting PSE. It therefore seems consensual that PSE contributes to the global development of children and positively influences their subsequent academic performance.

These data point to a positive conception about PSE and its impacts on children on the part of $1^{\text {st }} \mathrm{CBE}$ teachers, even though there is still room for improving articulation and reciprocal knowledge among the professionals of these two levels of education and teaching.

\subsection{To know the perspectives of parents / caregivers about the work carried out in PSE}

Most of the dimensions of the work carried out in PSE that parents/ caregivers were questioned about receives expressively positive appraisals by these stakeholders (with over $75 \%$ of answers indicating full agreement), as can be analyzed in the table below: 
Table 4. Work carried out in PSE - Parents'/ Caregivers' perspectives

\begin{tabular}{l|c|c|c|c|c}
\hline \hline $\begin{array}{c}\text { Dimensions of the work } \\
\text { carried out in PSE }\end{array}$ & I disagree & $\begin{array}{c}\text { I parcially } \\
\text { disagree }\end{array}$ & $\begin{array}{c}\text { I don't agree } \\
\text { or disagree }\end{array}$ & I agree & I fully agree \\
\hline $\begin{array}{l}\text { To support the family - to } \\
\text { take care of the child }\end{array}$ & $2 \%$ & $2 \%$ & $12 \%$ & $23 \%$ & $61 \%$ \\
\hline To develop competencies & $0 \%$ & $0 \%$ & $6 \%$ & $15 \%$ & $79 \%$ \\
\hline To promote socialization & $0 \%$ & $0 \%$ & $5 \%$ & $18 \%$ & $77 \%$ \\
\hline To promote autonomy & $0 \%$ & $0 \%$ & $6 \%$ & $18 \%$ & $76 \%$ \\
\hline $\begin{array}{l}\text { To prepare children for } \\
\text { mandatory schooling }\end{array}$ & $0 \%$ & $2 \%$ & $6 \%$ & $13 \%$ & $79 \%$ \\
\hline \hline
\end{tabular}

It is noteworthy that $61 \%$ of parents / caregivers fully agree PSE has a dimension of support to the family, as caregivers, which is in agreement with the law no $5 / 97$, of February $10^{\text {th }}$, which defends the complementary role of PSE to the educational action of the family.

Almost all (94\%) of parents/ caregivers consider they take part in the school lives of their children. However, only about half consider they are fully informed about the objectives of the work carried out with their children.

The information that the parents/ caregivers have about PSE, it is obtained:

- Through the activities developed by their children - $66 \%$ of respondents;

- Through contact with other parents - $24 \%$ of respondents;

- Through contact with the preschool educator - $23 \%$ of respondents;

- Through individual research - $10 \%$ of respondents;

- Through the school cluster's website - 5\% of respondents.

Eighty-six percent of the parents/ caregivers consider they frequently speak to their children about their day-to-day in the preschool. The subjects which are of greater concern to them, are: accompanying their children's learnings (84\%); the work carried out in the PSE classroom (70\%); their children's behavior $(60 \%)$, and their daily routines $(52 \%)$.

When questioned about their participation/ attendance at the preschool as parents/ caregivers, $48 \%$ refer they participate in their children's PSE of their own initiative; whereas $47 \%$ refer to only go to preschool when summoned by the preschool educator. In this sense, Medeiros [8] stresses the importance of family participation in the preschool's activities and the benefits to children that arise from a curriculum building process that is shared with the families.

Taking into account a historical outlook on the perspectives of caregivers of the children frequenting PSE about the roles played by this level of education, we can verify that expectations have evolved towards the valuing of the pedagogical dimension and intentionality of the work carried out in the activity room. No longer is there markedly a perspective of guardianship, as was the place in the XIX century. Results show that parents/ caregivers believe this age span, between the ages of 3 and 5 , is crucial in the lives and development of children. Attending preschool allows children to engage in rich experiences, equipping them to learn and want to learn.

\section{CONCLUSIONS}

The present study has revealed that all the stakeholders considered (preschool educators, $1^{\text {st }} \mathrm{CBE}$ teachers and parents/ caregivers) know that PSE has its own curricular work matrix, the CGPE. However, not all $1^{\text {st }}$ CBE teachers or parents/ caregivers have an in-depth knowledge of this document. Both $1^{\text {st }} \mathrm{CBE}$ teachers and parents/ caregivers acknowledge that the work carried out in PSE is guided in such a way as to facilitate further learning by their students or children.

It is important to stress that despite the structural role of the CGPE, preschool educators use other sources when elaborating curriculum, among which the children themselves stand out. Children assume an active role in the elaboration and contextualization of curriculum, adjusting the curricular 
proposals to the reality of the contexts where they are to be implemented. This reveals the transversal nature of the process of curriculum development, in terms of the levels and contexts of curricular decision, which span from a global level, to the micro level of the activities room. Curriculum making is not limited to a political or administrative level of decision-making [7]. The flexibility which is recognized in the CGPE is important to the perspective espoused by these preschool educators, that is, to the recognition that preschool educators are also curricular decision-makers.

Despite this positive perspective, preschool educators acknowledge the possibility of improving this instrument/referential, namely in what concerns the articulation with the $1^{\text {st }}$ CBE - this was corroborated by the teachers of this level of education who participated in the study. A qualitative analysis of the processes and practices of articulation present among professionals of these levels of education and teaching, as well a look into the limitations hindering the promotion of such practices, might be of great interest to future studies. Likewise, it would be important for future studies to understand the expectations of parents/caregivers for the future of their children - knowledge of their aspirations might relate to the knowledge and value placed on the work of PSE, as well as with the personal investment they make in the education of their children. It would also be relevant to carry out a longitudinal study, comparing academic and social results of children who did and did not attend PSE.

To conclude, it would be important to create more synergies among preschool educators, $1^{\text {st }} \mathrm{CBE}$ teachers and parents/ caregivers, through global projects, directed at the development of children.

\section{REFERENCES}

[1] Lei Quadro da Educação Pré-Escolar, Decreto-lei 5/97. Retrieved from: https://dre.pt/application/dir/pdf1s/1997/02/034A00/06700673.pdf

[2] I. Silva, L. Marques, L. Mata, and M. Rosa, Orientações curriculares para a educação pré-escolar. Lisbon/Porugal: Ministério da Educação, 2020.

[3] F. Sousa, "O currículo para a educação pré-escolar entre o específico e o comum: o caso das OCEPE", Revista de Estudos Curriculares, vol.9, n.1, pp. 24-44, 2018. Retrieved from https://www.nonio.uminho.pt/rec/index.php/rec/issue/view/6/showToc

[4] B. Clarke, S. Baker, K. Smolkowski, and D. J. Chard. "An Analysis of Early Numeracy CurriculumBased Measurement Examining the Role of Growth in Student Outcomes". Remedial and Special Education, vol. 29, no.1, pp. 46-57, 2008.

[5] T. Pestana, and J.A. Pacheco. "Currículo, tecnologias e inovação: para uma discussão da aprendizagem em contextos educacionais", Revista Linhas, vol.14, nº. 27, pp. 45-58, 2013.

[6] I. Abreu Lima, A. I. Pinto, C. Grande, J. Cadima, L. Mata, J. Pimentel, and S. Marinho, Caracterização dos contextos de educação pré-escolar. Inquérito extensivo. Relatório final, UP/ISPA/DGE, 2014. Retrieved from http://www.dge.mec.pt/ estudo-de-avaliacao-dasorientacoes-curriculares-e-da-qualidade-na-educacaopre-escolar

[7] M. I. Gaspar, and M.C. Roldão, Elementos do Desenvolvimento Curricular. Lisbon/Portugal: Universidade Aberta, 2007.

[8] T. Medeiros, A importância da participação da família na construção do currículo na educação de infância, Mestrado em Educação Pré-Escolar, Portalegre: Escola Superior de Educação de Portalegre. 